Research Article

\title{
Water-Cement-Density Ratio Law for the 28-Day Compressive Strength Prediction of Cement-Based Materials
}

\author{
Siqi Li, ${ }^{1}$ Jinbo Yang $\mathbb{D},{ }^{1}$ and Peng Zhang ${ }^{2}$ \\ ${ }^{1}$ School of Civil Engineering, College of Water Conservancy and Civil Engineering, Shandong Agricultural University, Taian, \\ Shandong 271018, China \\ ${ }^{2}$ School of Civil Engineering, Qingdao University of Technology, Qingdao 266033, China \\ Correspondence should be addressed to Jinbo Yang; yangjinbo@tsinghua.org.cn
}

Received 4 May 2020; Accepted 26 June 2020; Published 13 July 2020

Academic Editor: Shazim A. Memon

Copyright (c) 2020 Siqi Li et al. This is an open access article distributed under the Creative Commons Attribution License, which permits unrestricted use, distribution, and reproduction in any medium, provided the original work is properly cited.

\begin{abstract}
In the present contribution, the water-cement-density ratio law for the standard curing 28-day compressive strength of cementbased materials including grout, normal concrete, ceramsite concrete, and foamed concrete is proposed. The standard curing 28day compressive strength of different grouts, normal concrete, ceramsite concrete, and foamed concrete was tested. Simulations for Abrams' law, Bolomey's formula, and water-cement-density ratio law were carried out and compared. The water-cementdensity ratio law illustrates better simulations for the prediction of the 28-day compressive strength of cement-based materials. The water-cement-density ratio law includes both the water-cement ratio and relative apparent density of the cement-based material. Relative apparent density of the cement-based material is an important one of all the factors determining the compressive strength of the cement-based material. The water-cement-density ratio law will be beneficial for the precise and generalized prediction of the 28-day standard curing compressive strength of cement-based materials.
\end{abstract}

\section{Introduction}

Portland cement-based materials such as grout, normal concrete, lightweight concrete, and foamed concrete have an extremely wide scale of application in civil engineering construction throughout the world and are expected to be used more extensively in the future as well. Properties of cement-based materials are determined by the whole component raw materials and their proportions. Clearly and correctly understanding the physical connection between property and composition of cement-based materials is very important. In other words, precise and generalized prediction of properties based on composition of cement-based materials will be beneficial for engineering design and application of cement-based materials. The 28-day compressive strength is one of the first and foremost properties of cement-based materials for structural design of civil engineering. So far, how the 28-day compressive strength is determined by the composition of cement-based materials is not understood clearly enough.
Since the invention of Portland cement in 1824, plenty of research works have proved that the 28-day compressive strength of cement-based materials is determined by raw materials including cement, supplementary cementitious materials, aggregate etc., proportions including water-cement ratio, sand-aggregate ratio, cement content, etc., and curing conditions including ambient temperature, pressure, and humidity. In 1918, Abrams pronounced the water-cement ratio law based on the observation that as the watercement ratio decreases, the strength of the concrete increases, accordingly. In 1935, Bolomey gave a formula to predict the compressive strength of cement mortar which expresses a linear relationship between the water-cement ratio and compressive strength. Abrams' law and Bolomey's formula both indicate that compressive strength of cementbased materials is mainly dependent on the water-cement ratio among all the other factors. Therefore, Abrams' law and Bolomey's formula are seen as different mathematical forms of water-cement ratio law. For mortar, it has been found that cement-sand ratio, supplementary cementitious material 
content, and cement type all will influence the parameters in Abrams' law or Bolomey's formula [1-4]. For normal concrete, cement type, curing age, and silica fume content all will influence the parameters in Abrams' law or Bolomey's formula [5-8]. For lightweight concrete, properties of the aggregates will influence the parameters in Abrams' law or Bolomey's formula [9]. For foamed concrete, curing conditions, cement type, foaming agent, and dry density will influence the parameters in Abrams' law or Bolomey's formula $[10,11]$. However, so far, there were less efforts for generalization of Abrams' law or Bolomey's formula for cement-based materials including mortar, normal concrete, lightweight concrete, and foamed concrete all together.

In this contribution, the 28-day compressive strength of cement-based materials including grout, normal concrete, lightweight concrete, and foamed concrete was investigated. Abrams' law and Bolomey's formula were applied for simulation of the relationship between water-cement ratio and 28-day compressive strength. A novel water-cementdensity ratio law was proposed and verified. This work will be beneficial further for prediction of durability properties by composition of cement-based materials and durability study of cement-based material structure [12-18].

\section{Water-Cement Ratio Law and Water-Cement- Density Ratio Law}

The mathematical relationship between compressive strength and water-cement ratio, according to Abrams' law, is shown in the following equation:

$$
\sigma_{c}=\left(\frac{a_{1}}{a_{2}}\right)^{W / C},
$$

where $\sigma_{c}$ is the compressive strength of cement-based material (MPa), $W / C$ is the water-cement ratio, and $a_{1}$ and $a_{2}$ are parameters determined by cement type, cement content, curing condition, etc.

The mathematical relationship between compressive strength and water-cement ratio, according to Bolomey's formula, is shown in the following equation:

$$
\sigma_{c}=\frac{b_{1}}{W / C}-b_{2}
$$

where $b_{1}$ and $b_{2}$ are parameters determined by cement type, cement content, curing condition, etc.

The water-cement-density ratio law assumes that compressive strength of cement-based materials is mainly dependent on the water-cement-density ratio among all the other factors. The mathematical relationship between compressive strength and water-cement-density ratio, according to the water-cement-density ratio law, is shown in the following equation:

$$
\sigma_{c}=d_{1}+\left(\frac{d_{2}}{d_{3}}\right)^{(W / C) / D_{\mathrm{r}}},
$$

where $D_{\mathrm{r}}$ is the apparent relative density of the cement-based material, $(W / C) / D_{\mathrm{r}}$ is the water-cement-density ratio, and $d_{1}, d_{2}$, and $d_{3}$ are parameters determined by cement type, cement content, curing condition, etc.

If cement and supplementary cementitious materials together are seen as binder, the water-binder-density ratio law assumes that compressive strength of cement-based materials is mainly dependent on the water-binder-density ratio among all the other factors. The mathematical relationship between compressive strength and water-binderdensity ratio, according to the water-binder-density ratio law, is shown in the following equation:

$$
\sigma_{c}=f_{1}+\left(\frac{f_{2}}{f_{3}}\right)^{(W / B) / D_{\mathrm{r}}},
$$

where $W / B$ is the water-binder ratio, $(W / B) / D_{\mathrm{r}}$ is the waterbinder-density ratio, and $f_{1}, f_{2}$, and $f_{3}$ are parameters determined by cement type, cement content, curing condition, etc.

\section{Experimental}

3.1. Materials. P.I 42.5 Portland cement (PC) was used in accordance with Chinese national standard GB175-2007 (CEM I type Portland cement conforming to BS EN 197-1: 2011). Silica fume (SF) used has specific surface area of $16000 \mathrm{~m}^{2} / \mathrm{kg}$. Ground granulated blast furnace slag (GGBS) has a particle size ranging from $0.5 \mu \mathrm{m}$ to $125.8 \mu \mathrm{m}$. Fly ash with specific surface area of $380 \mathrm{~m}^{2} / \mathrm{kg}$ was used. The chemical composition of PC, SF, GGBS, and FA is shown in Table 1. Water reducer used is polycarboxylic acid superplasticizer. Coarse aggregates were crushed limestone aggregates with a maximum diameter of $30 \mathrm{~mm}$ and density of $2615 \mathrm{~kg} / \mathrm{m}^{3}$. Local river sand with a maximum grain size of $5 \mathrm{~mm}$ and density of $2630 \mathrm{~kg} / \mathrm{m}^{3}$ was adopted. Lightweight aggregates were expanded shale ceramsite aggregates with the maximum diameter of $20 \mathrm{~mm}$ and loose bulk density of $450 \mathrm{~kg} / \mathrm{m}^{3}$. Animal protein foaming agent was used for foamed concrete.

3.2. Mixture Proportions. Mixture proportions of grout, normal concrete, ceramsite concrete, and foamed concrete are shown in Tables 2-5, respectively. For grout, mixtures G0.20, G0.25, G0.30, and G0.40 are neat cement grouts. For normal concrete, silica fume is added in mixtures NC0.31, NC0.29, NC0.25, and NC0.20. For ceramsite concrete, the sand to aggregate ratio is changed from $32 \%$ to $42 \%$. For foamed concrete, the water to cement ratio is changed from 0.60 to 1.43 .

3.3. Test Methods and Sample Preparation. The compressive strength test was carried out conforming to BS EN 12390-3: 2009. The test specimens were prepared using standard metallic cube mould of size $10 \mathrm{~cm} \times 10 \mathrm{~cm} \times 10 \mathrm{~cm}$ and covered with plastic sheet after moulding for three days. After demoulding, all specimens were cured at $>95 \% \mathrm{RH}$ and $20 \pm 2^{\circ} \mathrm{C}$ for 28 days. The compressive strength was calculated as the average of three test specimens. The specimens were experimented at room temperature of $20 \pm 2^{\circ} \mathrm{C}$ with a 
TABle 1: Chemical composition of PC, SF, GGBS, and FA.

\begin{tabular}{|c|c|c|c|c|c|c|c|c|c|c|}
\hline \multirow{2}{*}{ Materials } & \multicolumn{9}{|c|}{ Chemical composition (\%) } & \multirow{2}{*}{ Loss on ignition (\%) } \\
\hline & $\mathrm{SiO}_{2}$ & $\mathrm{Al}_{2} \mathrm{O}_{3}$ & $\mathrm{Fe}_{2} \mathrm{O}_{3}$ & $\mathrm{CaO}$ & $\mathrm{MgO}$ & $\mathrm{SO}_{3}$ & Equivalent alkali & Free $\mathrm{CaO}$ & $\mathrm{Cl}^{-}$ & \\
\hline $\mathrm{PC}$ & 20.13 & 20.13 & 3.67 & 63.89 & 1.61 & 3.31 & 0.24 & 0.52 & 0.035 & 2.50 \\
\hline SF & 88.52 & 1.23 & 2.11 & 5.45 & 0.11 & - & - & - & - & 1.53 \\
\hline GGBS & 36.50 & 20.30 & 1.54 & 31.40 & 5.31 & 2.50 & 0.29 & - & - & 1.59 \\
\hline FA & 51.98 & 28.37 & 5.64 & 4.30 & 0.84 & 0.95 & - & - & - & 6.03 \\
\hline
\end{tabular}

TABLE 2: Mixture proportions of grout.

\begin{tabular}{|c|c|c|c|c|c|c|c|}
\hline \multirow{3}{*}{ Mixture ID } & \multirow{3}{*}{$W / C$} & \multicolumn{6}{|c|}{ Compositions $\left(\mathrm{kg} / \mathrm{m}^{3}\right)$} \\
\hline & & \multicolumn{3}{|c|}{ Binder } & \multirow{2}{*}{ Sand } & \multirow{2}{*}{ Water } & \multirow{2}{*}{ Water reducer } \\
\hline & & Cement & SF & GGBS & & & \\
\hline G0.20 & 0.20 & 1933 & 0 & 0 & 0 & 387 & 15 \\
\hline G0.25 & 0.25 & 1762 & 0 & 0 & 0 & 441 & 5.0 \\
\hline G0.30 & 0.30 & 1620 & 0 & 0 & 0 & 486 & 4.0 \\
\hline G0.40 & 0.40 & 1394 & 0 & 0 & 0 & 558 & 2.0 \\
\hline G0.26 & 0.26 & 746 & 123 & 153 & 1279 & 194 & 8.0 \\
\hline G0.33 & 0.33 & 674 & 92 & 255 & 1279 & 225 & 5.0 \\
\hline G0.28 & 0.28 & 909 & 61 & 51 & 1279 & 255 & 4.0 \\
\hline G0.24 & 0.24 & 1176 & 38 & 64 & 1021 & 281 & 5.0 \\
\hline
\end{tabular}

TABLE 3: Mixture proportions of normal concrete.

Compositions $\left(\mathrm{kg} / \mathrm{m}^{3}\right)$

\begin{tabular}{|c|c|c|c|c|c|c|c|c|c|}
\hline \multirow[t]{2}{*}{ Mixture ID } & \multirow[t]{2}{*}{$W / C$} & \multirow[t]{2}{*}{ Water-binder ratio } & \multirow[t]{2}{*}{ Sand to aggregate ratio } & \multicolumn{2}{|c|}{ Binder } & \multirow{2}{*}{ Sand } & \multirow{2}{*}{ Coarse aggregate } & \multirow{2}{*}{ Water } & \multirow{2}{*}{ Water reducer } \\
\hline & & & & Cement & SF & & & & \\
\hline NC0.48S & 0.48 & 0.48 & 0.45 & 500 & 0 & 700 & 850 & 240 & 5.40 \\
\hline NC0.45S & 0.45 & 0.45 & 0.45 & 500 & 0 & 700 & 850 & 220 & 6.00 \\
\hline NC0.38S & 0.38 & 0.38 & 0.45 & 500 & 0 & 700 & 850 & 190 & 8.80 \\
\hline NC0.34S & 0.34 & 0.34 & 0.45 & 500 & 0 & 700 & 850 & 170 & 9.60 \\
\hline NC0.38 & 0.38 & 0.38 & 0.38 & 400 & 0 & 700 & 1125 & 152 & 3.00 \\
\hline NC0.34 & 0.34 & 0.34 & 0.38 & 400 & 0 & 700 & 1125 & 136 & 4.25 \\
\hline NC0.30 & 0.30 & 0.30 & 0.38 & 400 & 0 & 700 & 1125 & 120 & 4.25 \\
\hline NC0.31 & 0.31 & 0.28 & 0.41 & 600 & 67 & 550 & 800 & 187 & 6.75 \\
\hline NC0.29 & 0.29 & 0.26 & 0.41 & 600 & 67 & 550 & 800 & 173 & 6.75 \\
\hline NC0.25 & 0.25 & 0.22 & 0.41 & 600 & 67 & 550 & 800 & 147 & 8.00 \\
\hline NC0.20 & 0.20 & 0.18 & 0.41 & 600 & 67 & 550 & 800 & 120 & 8.00 \\
\hline
\end{tabular}

TABLE 4: Mixture proportions of ceramsite concrete.

\begin{tabular}{|c|c|c|c|c|c|c|c|c|}
\hline \multirow{3}{*}{ Mixture ID } & \multirow{3}{*}{$W / C$} & \multirow{3}{*}{ Sand to aggregate ratio } & \multicolumn{6}{|c|}{ Compositions $\left(\mathrm{kg} / \mathrm{m}^{3}\right)$} \\
\hline & & & \multicolumn{2}{|c|}{ Binder } & \multirow{2}{*}{ Sand } & \multirow{2}{*}{ Ceramsite aggregate } & \multirow{2}{*}{ Water } & \multirow{2}{*}{ Water reducer } \\
\hline & & & Cement & FA & & & & \\
\hline CC0.55-32 & 0.55 & 0.32 & 380 & 38 & 508 & 312 & 209 & 0 \\
\hline CC0.51-30 & 0.51 & 0.30 & 380 & 48 & 530 & 303 & 193 & 0 \\
\hline CC0.51-35 & 0.51 & 0.35 & 380 & 48 & 607 & 363 & 193 & 0 \\
\hline CC0.51-42 & 0.51 & 0.42 & 380 & 48 & 743 & 303 & 193 & 0 \\
\hline
\end{tabular}

TABle 5: Mixture proportions of foamed concrete.

\begin{tabular}{|c|c|c|c|c|c|c|c|}
\hline \multirow{3}{*}{ Mixture ID } & \multirow{3}{*}{$W / C$} & \multirow{3}{*}{ Water-binder ratio } & \multicolumn{5}{|c|}{ Compositions $\left(\mathrm{kg} / \mathrm{m}^{3}\right)$} \\
\hline & & & \multicolumn{3}{|c|}{ Binder } & \multirow{2}{*}{ Water } & \multirow{2}{*}{ Foaming agent } \\
\hline & & & Cement & GGBS & FA & & \\
\hline FC0.60 & 0.60 & 0.45 & 600 & 80 & 120 & 360 & 3.60 \\
\hline FC0.67 & 0.67 & 0.50 & 600 & 80 & 120 & 400 & 3.60 \\
\hline FC0.91 & 0.91 & 0.50 & 440 & 160 & 200 & 400 & 3.60 \\
\hline FC1.43 & 1.43 & 0.50 & 280 & 240 & 280 & 400 & 3.60 \\
\hline
\end{tabular}


relative humidity of $65 \%$. Apparent relative density was determined after demoulding by weighting using electronic scale and volume calculation using checked dimensions.

\section{Results and Discussion}

\subsection{Respective Results and Discussion for Different Cement- Based Materials}

4.1.1. Grout. Simulations of Abrams' law and Bolomey's formula for grout were carried out, and the results are shown in Figure 1. Abrams' law and Bolomey's formula both have good simulations with $R$-square of 0.9733 and 0.9637 , respectively. Parameters $a_{1}$ and $a_{2}$ of Abrams' law are 245 and 66. Parameters $b_{1}$ and $b_{2}$ of Bolomey's formula are 26 and 19. Simulations of water-cement-density ratio law for grout were carried out, and the results are shown in Figure 2. Watercement-density ratio law has a good simulation with $R$-square of 0.9776 . Parameters $d_{1}, d_{2}$, and $d_{3}$ of water-cement-density ratio law are $2.4,200$, and 2174 , respectively. Water-cementdensity ratio law includes both the water-cement ratio and apparent density of the cement-based material.

4.1.2. Normal Concrete. Simulations of Abrams' law and Bolomey's formula for normal concrete were carried out, and the results are shown in Figure 3. Abrams' law and Bolomey's formula both have good simulations with $R$-square of 0.9070 and 0.9293 , respectively. Parameters $a_{1}$ and $a_{2}$ of Abrams' law are 287 and 79. Parameters $b_{1}$ and $b_{2}$ of Bolomey's formula are 33 and 33. Simulations of watercement-density ratio law for normal concrete were carried out using the same simulation parameters of grout as shown in Figure 2, and the results are shown in Figure 4. Watercement-density ratio law has a simulation with $R$-square of 0.6544 while parameters $d_{1}, d_{2}$, and $d_{3}$ of water-cementdensity ratio law are controlled to $2.4,200$, and 2174 , respectively. It also seemed that while water-cement ratio is higher than 0.3, the simulations are better because Abrams' law is valid over the range of water-cement ratios of 0.30 to $1.20[19,20]$. For low water-cement ratio, prediction of compressive strength is more complicated. The main reason is that for the cement-based material having high watercement ratio, a part of mixing water does not participate in cement hydration and finally forms pores in hardened hydration products which will determine the mechanical properties evidently. On the contrary, for the cement-based material having low water-cement ratio, most of the mixing water participates in cement hydration and then does not form more pores in hardened hydration products. Generally speaking, for low porosity solid materials, more attention should be paid to the influence of chemical composition and load action form on material properties [21-23].

4.1.3. Ceramsite Concrete. Simulations of Abrams' law and Bolomey's formula for ceramsite concrete were carried out, and the results are shown in Figure 5. Abrams' law and Bolomey's formula both have bad simulations with $R$-square of 0.0696. Parameters $a_{1}$ and $a_{2}$ of Abrams' law are 116 and

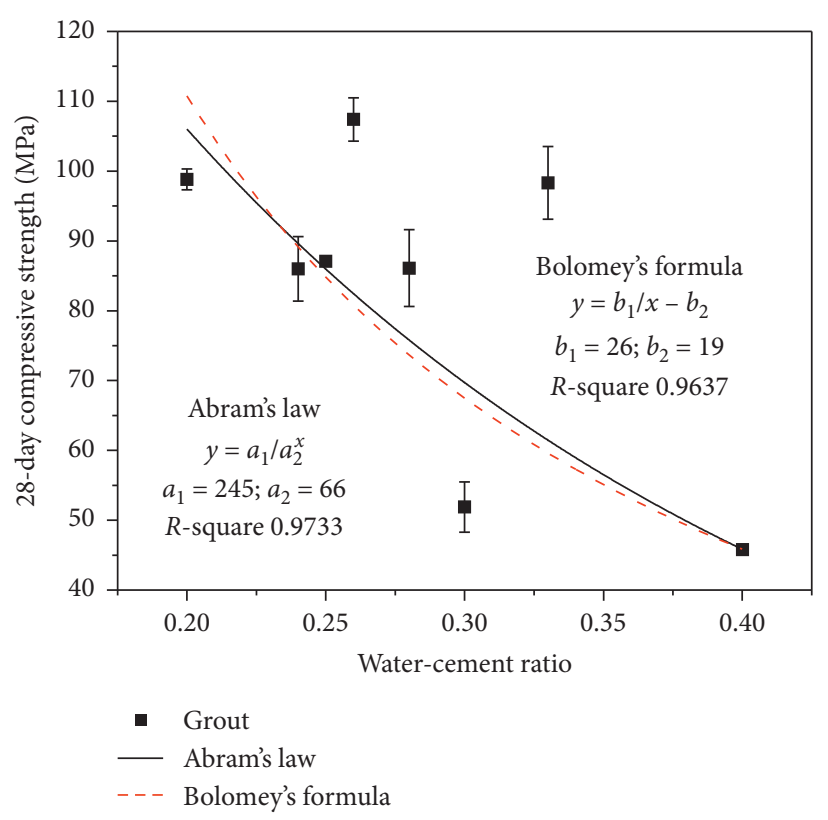

Figure 1: Simulations of Abrams' law and Bolomey's formula for grout.

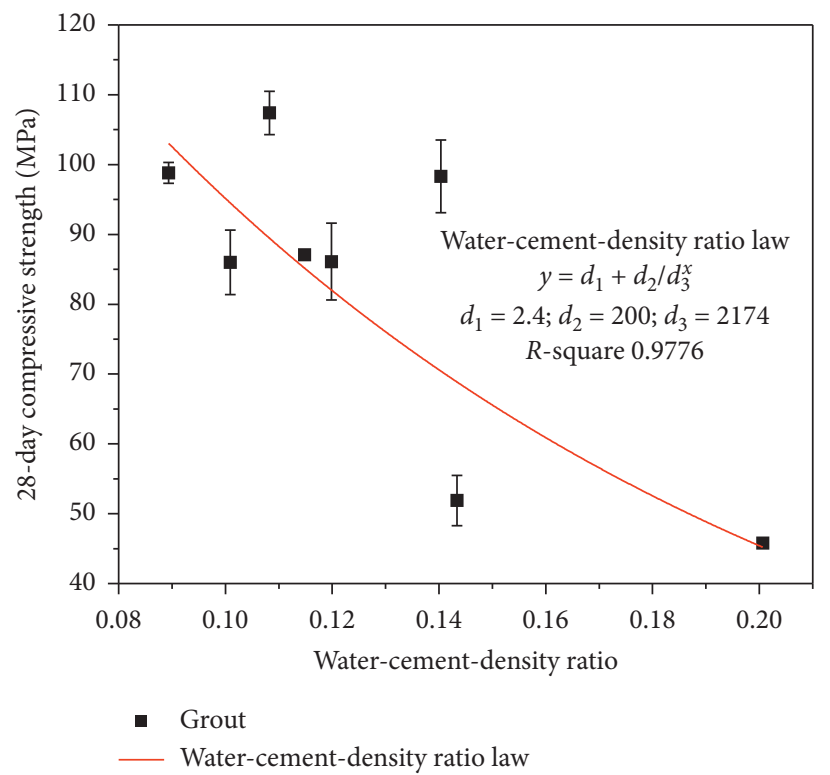

FIGURE 2: Simulation of water-cement-density ratio law for grout.

58. Parameters $b_{1}$ and $b_{2}$ of Bolomey's formula are 15.4 and 15.5. Simulations of water-cement-density ratio law for ceramsite concrete were carried out using the same simulation parameters of grout as shown in Figure 2, and the results are shown in Figure 6. Water-cement-density ratio law has a simulation with $R$-square of 0.5112 while parameters $d_{1}, d_{2}$, and $d_{3}$ of water-cement-density ratio law are controlled to $2.4,200$, and 2174 , respectively.

4.1.4. Foamed Concrete. Simulations of Abrams' law and Bolomey's formula for foamed concrete were carried out, and the results are shown in Figure 7. Abrams' law and 


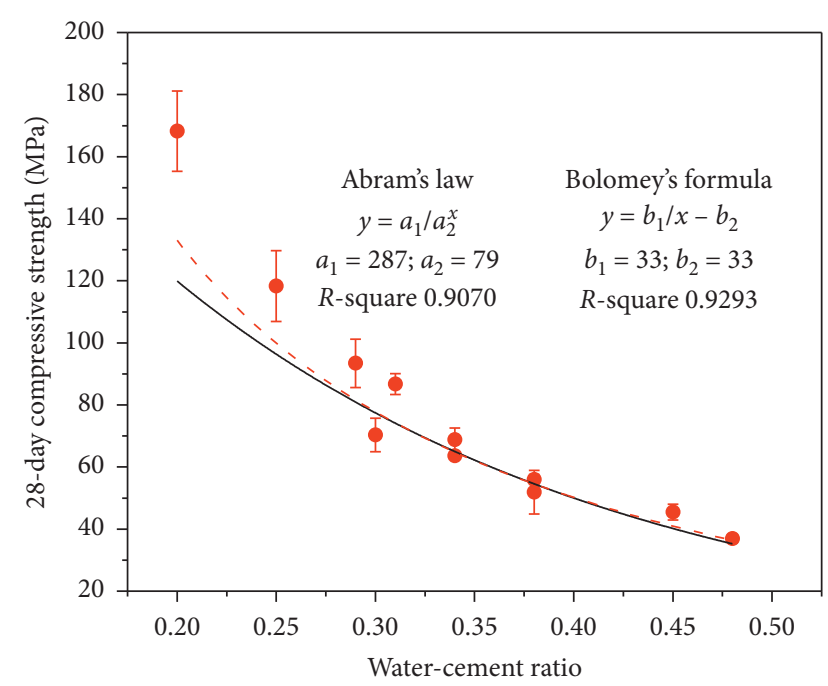

- Normal concrete
_ Abram's law
$\ldots$ _ Bolomey's formula

Figure 3: Simulations of Abrams' law and Bolomey's formula for normal concrete.

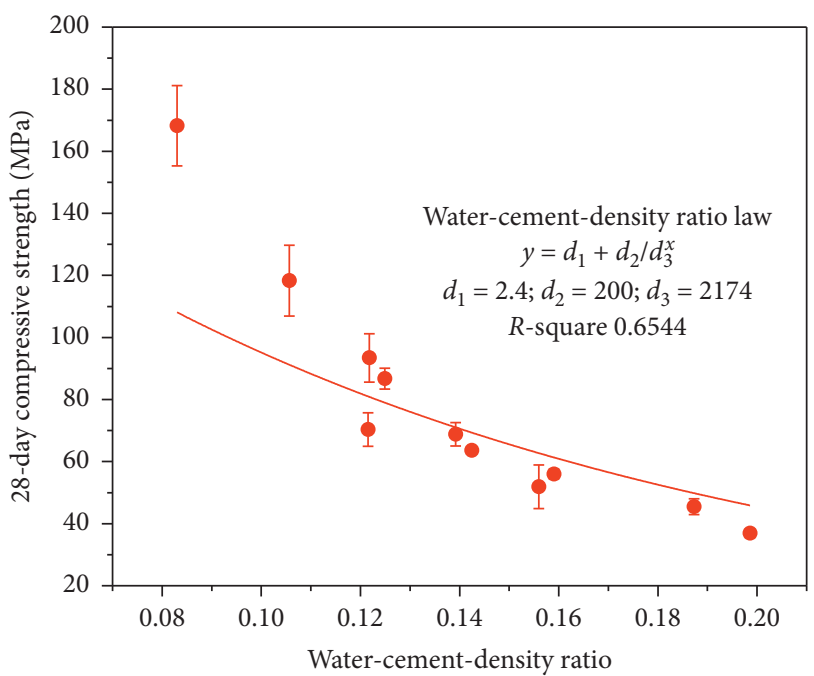

- Normal concrete

Water-cement-density ratio law

FIGURE 4: Simulation of water-cement-density ratio law for normal concrete.

Bolomey's formula both have bad simulations with $R$-square of 0.1605 and 0.3985 , respectively. Parameters $a_{1}$ and $a_{2}$ of Abrams' law are 2.8 and 1.1. Parameters $b_{1}$ and $b_{2}$ of Bolomey's formula are 0.35 and 2.12. Simulations of watercement-density ratio law for foamed concrete were carried out using the same simulation parameters of grout as shown in Figure 2, and the results are shown in Figure 8. Watercement-density ratio law has a simulation with $R$-square of 0.8154 while parameters $d_{1}, d_{2}$, and $d_{3}$ of water-cementdensity ratio law are controlled to 2.4, 200, and 2174, respectively.

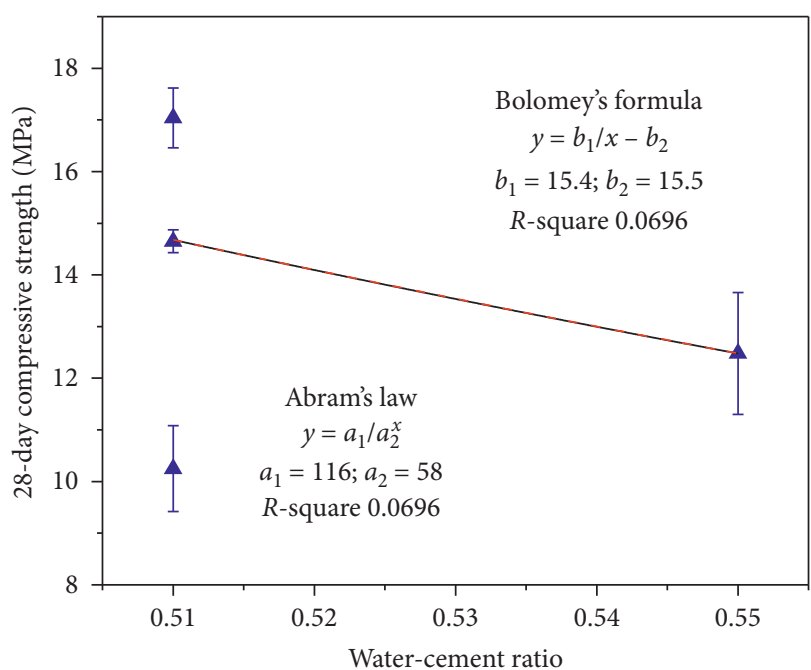

$\Delta \quad$ Ceramsite concrete
$-\ldots$ Abram's law
--- Bolomey's formula

FIgURE 5: Simulations of Abrams' law and Bolomey's formula for ceramsite concrete.

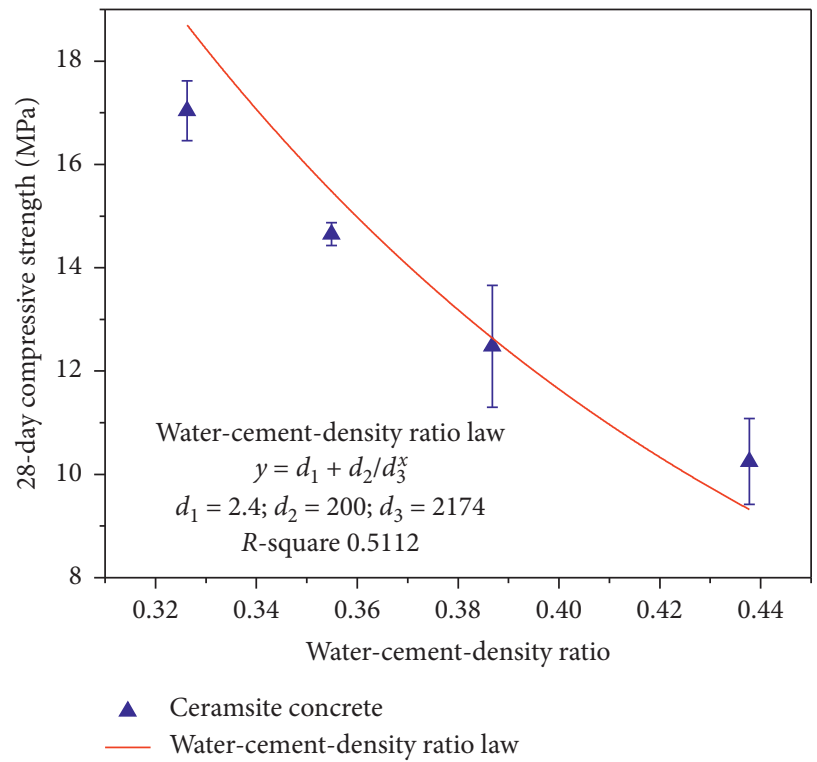

FIgURE 6: Simulation of water-cement-density ratio law for ceramsite concrete.

\subsection{Results and Discussion for General Cement-Based Materials}

4.2.1. Abrams' Law and Bolomey's Formula. Simulations of Abrams' law and Bolomey's formula using water-cement ratio for all cement-based materials were carried out, and the results are shown in Figure 9. Abrams' law and Bolomey's formula both have good simulations with $R$-square of 0.9391 and 0.8470 , respectively. Parameters $a_{1}$ and $a_{2}$ of Abrams' law are both 500. Parameters $b_{1}$ and $b_{2}$ of Bolomey's formula are 28 and 29. Figure 9 shows that for ceramsite concrete and foamed concrete, simulations of Abrams' law and Bolomey's 


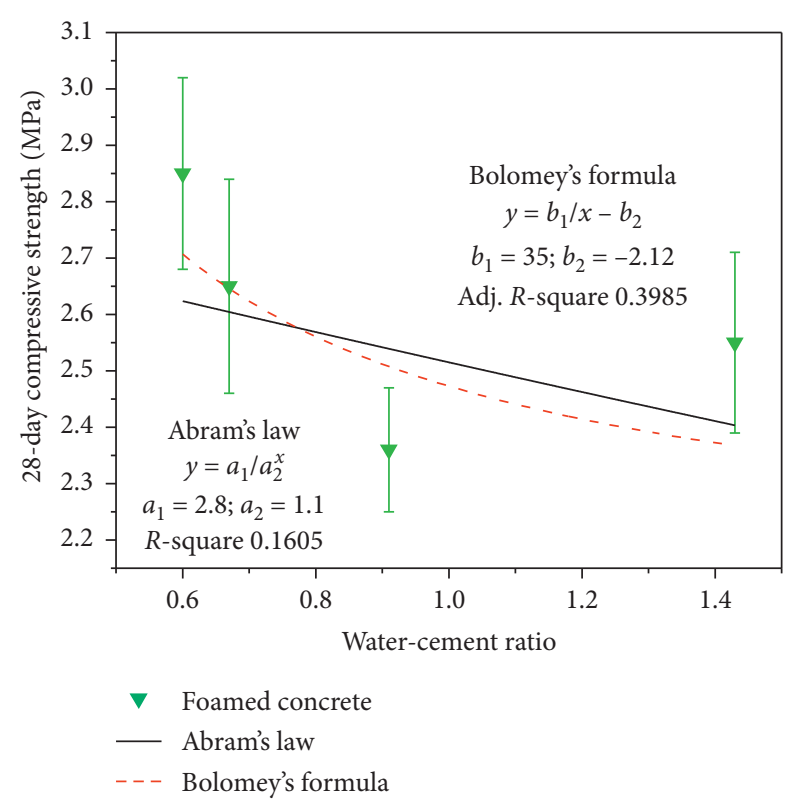

Figure 7: Simulations of Abrams' law and Bolomey's formula for foamed concrete.

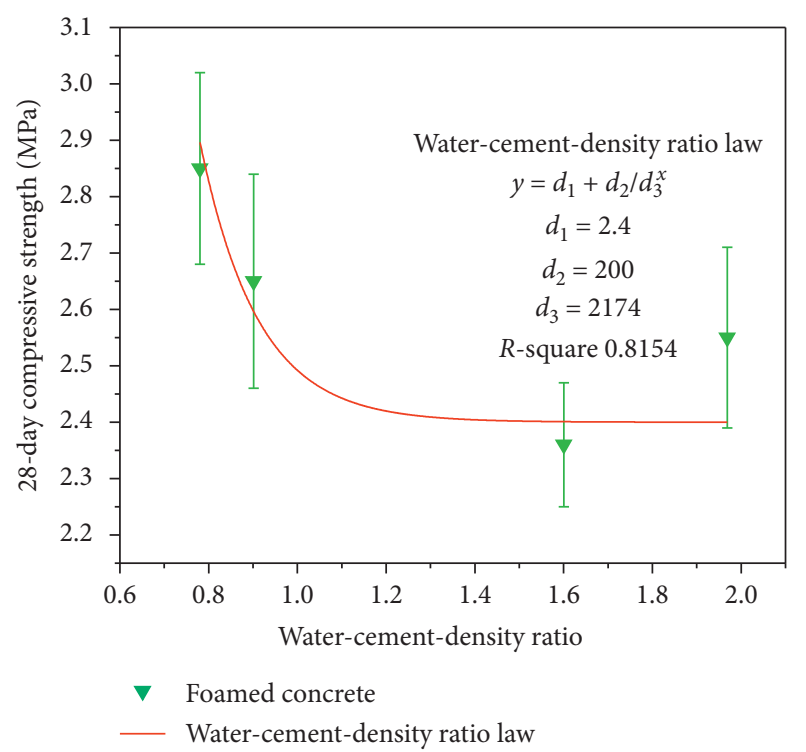

FIGURE 8: Simulation of water-cement-density ratio law for foamed concrete.

formula are not good. General simulation parameters are not uniform compared with the preceding individual simulations. Simulations of Abrams' law and Bolomey's formula using water-binder ratio for all cement-based materials were carried out, and the results are shown in Figure 10. Abrams' law and Bolomey's formula have simulations with $R$-square of 0.6210 and 0.7952 , respectively. Parameters $a_{1}$ and $a_{2}$ of Abrams' law are 987 and 5930. Parameters $b_{1}$ and $b_{2}$ of Bolomey's formula are 62 and 119. Comparison of Figures 9 and 10 shows that the water-cement ratio law has a better simulation.

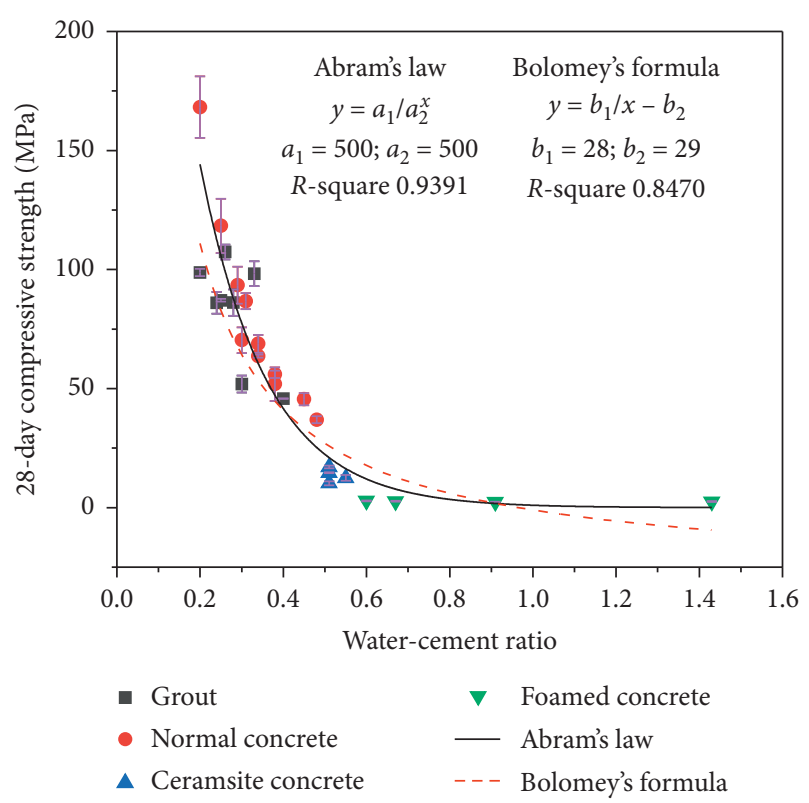

FIgURE 9: Simulations of Abrams' law and Bolomey's formula using water-cement ratio for cement-based materials.

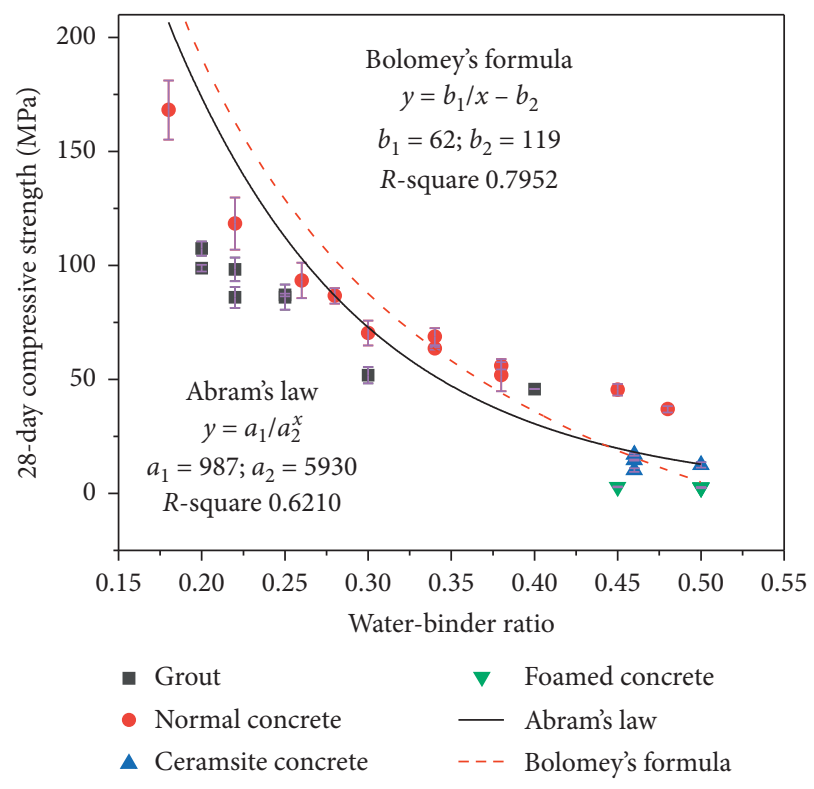

Figure 10: Simulations of Abrams' law and Bolomey's formula using water-binder ratio for cement-based materials.

4.2.2. Water-Cement-Density Ratio Law. Simulation of water-cement-density ratio law for all cement-based materials was carried out, and the results are shown in Figure 11. Water-cement-density ratio law has a good simulation with $R$-square of 0.9976 . Parameters $d_{1}, d_{2}$, and $d_{3}$ of water-cement-density ratio law are controlled to 2.4, 200, and 2174, respectively. General simulation parameters are uniform compared with the preceding individual simulations. Simulation of water-binder-density ratio law for all cementbased materials was carried out, and the results are shown in Figure 12. Water-binder-density ratio law has simulation 


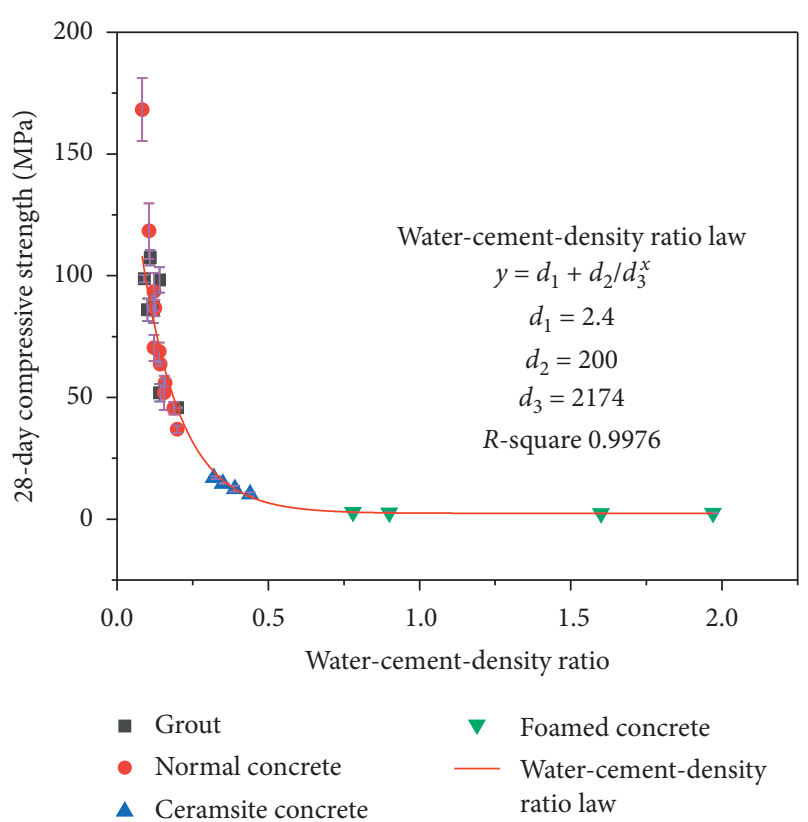

FIGURE 11: Simulation of water-cement-density ratio law for all cement-based materials.

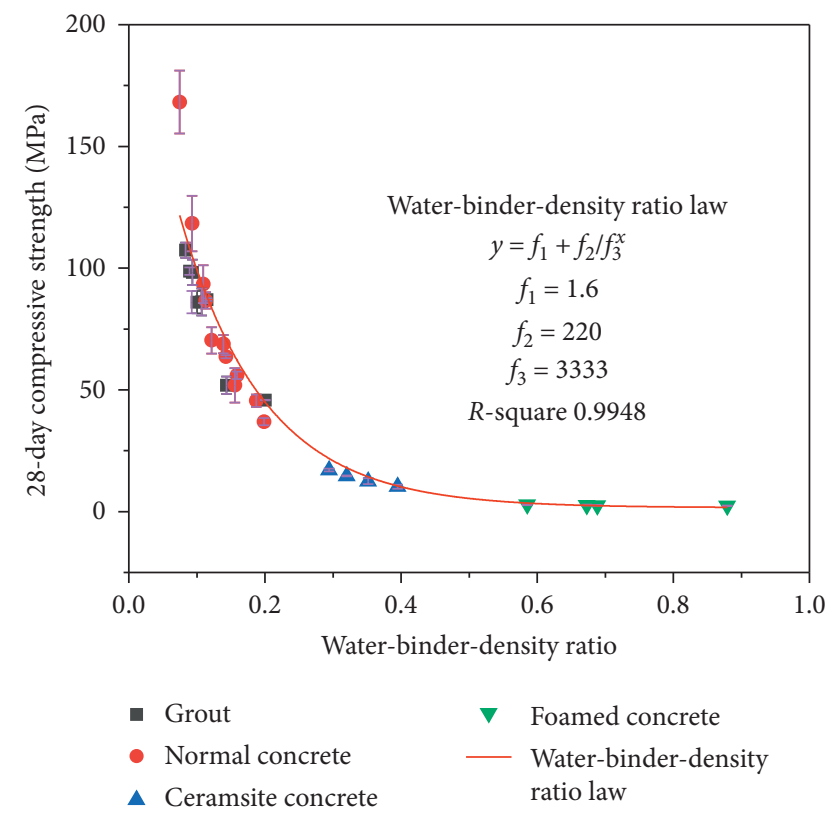

FIGURE 12: Simulation of water-binder-density ratio law for all cement-based materials.

with $R$-square of 0.9948 . Parameters $f_{1}, f_{2}$, and $f_{3}$ of waterbinder-density ratio law are 1.6, 220, and 3333, respectively. Comparison of Figures 11 and 12 shows that the watercement-density ratio law has a better simulation. It is reasonable to see that cement is still the main cementitious material in hydration and the hardening of cement hydration products determines mainly the mechanical properties of cement-based materials.

\section{Conclusions}

Based on the results identified in this study, the following conclusions are drawn. The novel water-cement-density ratio law is proposed based on water-cement ratio law. Compared with Abrams' law and Bolomey's formula, the water-cement-density ratio law illustrates better simulations for the prediction of the 28-day standard curing compressive strength of cement-based materials including grout, normal concrete, ceramsite concrete, and foamed concrete designed in this contribution over the range of water-cement ratios of 0.20 to 1.40 . The water-cement-density ratio law includes both the water-cement ratio and relative apparent density of the cement-based material. Relative apparent density of the cement-based material is an important one of all the factors determining the compressive strength of the cement-based material. The water-cement-density ratio law will be beneficial for the precise and generalized prediction of the 28-day standard curing compressive strength of cement-based materials. As a topic of future research, the effects of cement type and curing conditions on parameters of the watercement-density ratio law should be studied.

\section{Data Availability}

The data used to support the findings of this study are available from the corresponding author upon request.

\section{Conflicts of Interest}

The authors declare that they have no conflicts of interest.

\section{Acknowledgments}

The financial support for ongoing projects by the National Natural Science Foundation of China (51922052, U1706222, 51778309, and 51208013) and National Natural Science Foundation of Shandong Province (ZR2018JL018) is greatly acknowledged.

\section{References}

[1] G. A. Rao, "Generalization of Abrams' law for cement mortars," Cement and Concrete Research, vol. 31, no. 3, pp. 495-502, 2001.

[2] A. ElNemr, "Generating water/binder ratio-to-strength curves for cement mortar used in Masnory walls," Construction and Building Materials, vol. 233, Article ID 117249, 2020.

[3] G. A. Rao, "Role of water-binder ratio on the strength development in mortars incorporated with silica fume," Cement and Concrete Research, vol. 31, no. 3, pp. 443-447, 2001.

[4] A. Kargari, H. Eskandari-Naddaf, and R. Kazemi, "Effect of cement strength class on the generalization of Abrams' law," Structural Concrete, vol. 20, no. 1, pp. 493-505, 2019.

[5] T. S. Nagaraj and Z. Banu, "Generalization of Abrams' law," Cement and Concrete Research, vol. 26, no. 6, pp. 933-942, 1996.

[6] I.-C. Yeh, "Generalization of strength versus water-cementitious ratio relationship to age," Cement and Concrete Research, vol. 36, no. 10, pp. 1865-1873, 2006. 
[7] S. Bhanja and B. Sengupta, "Modified water-cement ratio law for silica fume concretes," Cement and Concrete Research, vol. 33, no. 3, pp. 447-450, 2003.

[8] E. M. Golafshani and A. Behnood, "Estimating the optimal mix design of silica fume concrete using biogeography-based programming," Cement and Concrete Composites, vol. 96, pp. 95-105, 2019.

[9] N. P. Rajamane and P. S. Ambily, "Modified Bolomey equation for strengths of lightweight concretes containing fly ash aggregates," Magazine of Concrete Research, vol. 64, no. 4, pp. 285-293, 2012.

[10] D. Falliano, D. De Domenico, G. Ricciardi, and E. Gugliandolo, "Experimental investigation on the compressive strength of foamed concrete: effect of curing conditions, cement type, foaming agent and dry density," Construction and Building Materials, vol. 165, pp. 735-749, 2018.

[11] Z. M. Yaseen, R. C. Deo, A. Hilal et al., "Predicting compressive strength of lightweight foamed concrete using extreme learning machine model," Advances in Engineering Software, vol. 115, pp. 112-125, 2018.

[12] F. Khademi, M. Akbari, S. M. Jamal, and M. Nikoo, "Multiple linear regression, artificial neural network, and fuzzy logic prediction of 28 days compressive strength of concrete," Frontiers of Structural and Civil Engineering, vol. 11, no. 1, pp. 90-99, 2017.

[13] P. Zhang, F. H. Wittmann, M. Vogel, H. S. Müller, and T. Zhao, "Influence of freeze-thaw cycles on capillary absorption and chloride penetration into concrete," Cement and Concrete Research, vol. 100, no. 10, pp. 60-67, 2017.

[14] P. Zhang, F. H. Wittmann, P. Lura, H. S. Müller, S. Han, and T. Zhao, "Application of neutron imaging to investigate fundamental aspects of durability of cement-based materials: a review," Cement and Concrete Research, vol. 108, pp. 152166, 2018.

[15] P. Zhang, D. Li, Y. Qiao, S. Zhang, C. T. Sun, and T. Zhao, "The effect of air entrainment on the mechanical properties, chloride migration and microstructure of ordinary concrete and fly ash concrete," Journal of Materials in Civil Engineering, vol. 30, no. 10, Article ID 04018265, 2018.

[16] J. Bao, S. Li, P. Zhang et al., "Influence of the incorporation of recycled coarse aggregate on water absorption and chloride penetration into concrete," Construction and Building Materials, vol. 239, Article ID 117845, 2020.

[17] S. Xue, P. Zhang, J. Bao, L. He, Y. Hu, and S. Yang, "Comparison of mercury intrusion porosimetry and multi-scale $\mathrm{X}$-ray CT on characterizing the microstructure of heat-treated cement mortar," Materials Characterization, vol. 160, Article ID 110085, 2020.

[18] R. Buši 'c, M. Benši 'c, I. Milǐcevi', and K. Strukar, "Prediction models for the mechanical properties of self-compacting concrete with recycled rubber and silica fume," Materials, vol. 13, p. 1821, 2020.

[19] L. K. A. Sear, J. Dews, B. Kite, F. C. Harris, and J. F. Troy, "Abrams law, air and high water-to-cement ratios," Construction and Building Materials, vol. 10, no. 3, pp. 221-226, 1996.

[20] S. Popovics and J. Ujhelyi, "Contribution to the concrete strength versus water-cement ratio relationship," Journal of Materials in Civil Engineering, vol. 20, no. 7, pp. 459-463, 2008.

[21] K. Zhao, Y. Qiao, P. Zhang, J. Bao, and Y. Tian, "Experimental and numerical study on chloride transport in cement mortar during drying process," Construction and Building Materials, vol. 258, Article ID 119655, 2020.

[22] J. Bao, S. Xue, P. Zhang, Z. Dai, and Y. Cui, "Coupled effects of sustained compressive loading and freeze-thaw cycles on water penetration into concrete," Structural Concrete, pp. 1$11,2020$.

[23] Q. Song, H. Y. Zhao, J. W. Jia et al., "Pyrolysis of municipal solid waste with iron-based additives: a study on the kinetic, product distribution and catalytic mechanisms," 2020 in Journal of Cleaner Production, vol. 258, Article ID 120682, 2020. 